\title{
ECO-FASHION DESIGNING TO ENSURE CORPORATE SOCIAL RESPONSIBILITY WITHIN THE SUPPLY CHAIN IN FASHION INDUSTRY
}

\author{
Warangkana Jutidamrongphan ${ }^{1}$, Md Ahbabur Rahman², Tareq Hossain ${ }^{3}$, Syeda Abida Khatun ${ }^{4}$, \\ Wendell de Queiróz Lamas ${ }^{5}$
}

1 Faculty of Environmental Management, Prince of Songkla University, Hat Yai, Songkhla, Thailand, E-mail: warangkana.j@psu.ac.th 2 Interdisciplinary Graduate School of Energy Systems (IGES), Prince of Songkla University, Hat Yai, Songkhla, Thailand, E-mail: muhammadahbab92@gmail.com

3 Thammasat Business School, Thammasat University, 2 Pranchan Road, Pranakorn, Bangkok- 10200, Thailand, E-mail: hossain@tbs.tu.ac.th 4 Department of Sustainable Energy Management, Faculty of Environmental Management, Prince of Songkla University, Hat Yai, Songkhla, Thailand, E-mail: adlife1717@gmail.com

5 Lorena School of Engineering, University of São Paulo, Lorena, SP, Brazil, E-mail: wendell.lamas@usp.br

${ }^{*}$ Corresponding author. E-mail: muhammadahbab92@gmail.com

\begin{abstract}
:
Fashion is a widespread cultural phenomenon which supports cultural attitudes and proposes new ways of acting. This study considers how ecological goals can be applied in the fashion industry through an awareness of its effects on the environment with the aim of conducting the process of designing and manufacturing fashion garments. To understand this needs practically, this study investigates on few industries in Hatyai municipality (Thailand) for knowing their practice on eco-fashion approach to support MSW management properly. The study adopts as its methodology a systematic review of relevant literature covering the twin problems of the degradation of the environment and the shortage of natural resources currently caused by the fashion-garment industry, in search of feasible solutions centred on the concept of eco-fashion. The study also addresses how the concept of ecological clothing can generate a new mentality among consumers. The study identifies concepts, techniques and processes which can economically be applied in producing fashion garments from a more ecologically sound starting point. This paper also sheds light on how corporate social responsibility (CSR) can be practiced within the fashion supply chain. This study contributes to the existing literature by assisting the understanding of the current situation of waste in the fashion-garment industry and the methods necessary to ensure eco-fashion designing and a responsible fashion supply chain.
\end{abstract}

\section{Keywords:}

CSR; waste management; ecological clothing; responsible supply chain; sustainable clothing.

\section{Introduction}

The textile industry has caused environmental problems to deepen due to the indiscriminate generation of industrial waste. Tonnes of garments after use are discarded and left as waste in most developed societies [1]. An immense amount of textile industry products have accumulated due to the simplification of production processes, and pollution expands at the pace of fashion throughout the world [2]. With the growth of ethical conscience and respect for the environment, and in order to achieve improvements in quality of life, an ecological balance must guide the production of fibres, yarns and fabrics $[3,4]$. Textile products can make a substantial contribution to increasing quality of life, particularly through products related to the safety and protection of people's lives. However, most garments are not currently biodegradable [5] and do not contribute to caring for the planet [6]. Therefore, the garment industry needs to develop products which take account of the social and environmental impact of the industry, such as those using natural materials, in order to offer consumers products in accord with the principle of social responsibility.
Moreover, fashion exerts different pressures throughout the world which are manifested both in society and the individual [7]. This results in a conflict between development and the constant acceleration of production caused by individualistic consumption and the growing ecological awareness spreading across different sectors of the economy. The life cycle of the fashion clothing industry is illustrated in Figure 1.

The textile and fashion industry is one of the largest in the world, employing one sixth of the world's working population [8]. After agriculture, this sector uses more water than any other [9]. It emits toxic chemical agents, uses enormous amounts of energy and is one of the main industries responsible for global warming [10]. Hence, it is important to consider its negative impacts and to discover solutions to them through the so called $3 R s$ (reuse, reduce, and recycle) which can adapt the industrial processes of the textile industry and the life cycle of its products into a more socially responsible corporate supply chain $[11,12]$. 


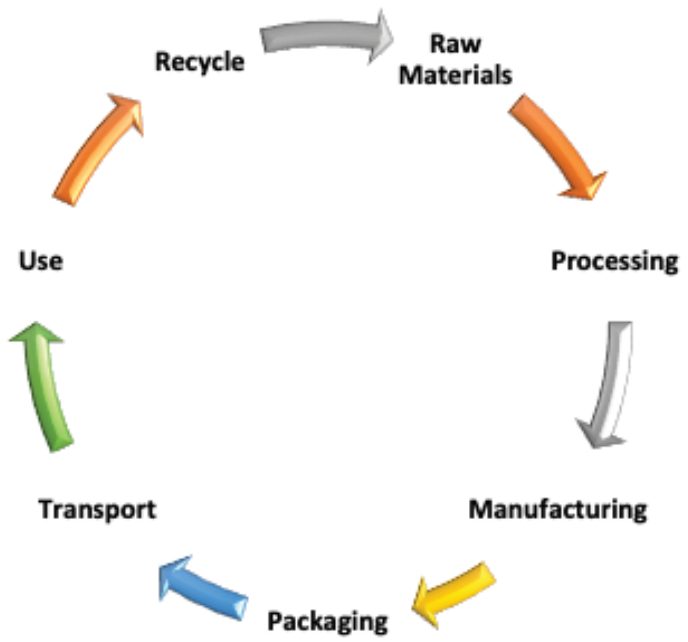

Figure 1. Life cycle of fashion clothing [5].

\subsection{The $3 R s$}

As illustrated in Figure 2, the $3 R$ s relate to different strategies aimed at decreasing the flow of new materials in an economic system. The aim of reusing, reducing, and recycling products is to prevent or postpone the disposal of used products in landfills etc., so that the resources used in their production can be returned to the economic system either by reusing or reducing them or by allowing them to be recycled as raw materials in an industrial process.

Reuse has been a long-standing stage in the life-cycle of garments and is as old as the industry itself. However, reuse activities vary according to the growth of consumption, expulsion and the influence of economic markets [13] . Moreover, there are many routes available for reusing garments, which promise different opportunities to create a socially responsible corporate supply chain [14]. The most obvious is the direct route in which second-hand clothes that are of good quality and in good condition are acquired by mediators and resold locally as vintage clothing at thrift stores, charity shops or secondhand fairs. This route produces employment and extends the life of garments, thus saving resources. However, not all reused clothes are disposed of locally and many are sent to used-clothing markets in different countries. The mediators facilitating the reuse of garments are generally charities or waste disposal companies who obtain the garments either through collection or donation from their original users. They have little control over the customs of the eventual users or the condition of the garment that they obtain by way of collection or donation and there has been a tendency to limit the amount of clothing supplied and its quality in order to increase profits. However, these methods of reuse will collapse unless the industry modifies its posture relating to waste processing and the value assigned to the materials both used or without previous use. It would be preferable if the eventual recovery of the garments formed an active part of the integral development of fashion [15].

The goal of reduce is to give life to discarded or damaged garments as a way of preventing them from being dumped or postponing that situation for as long as possible. There are abundant and diverse procedures to restore used, unwanted or damaged clothes to a usable condition, and nowadays a number of designers are working with recycled clothing to create new products, which fuse the recycling of used textiles with creativity and ornament [16]. In this way, they manage to invent unique creations by redesigning, and disassembling garments and manufacturing new garments or parts of them with the assistance of technology. These innovations can result in both a tendency for the reduction of the cost of the raw materials used as well as the possibility that the end product will have a value higher than the original product from which it was derived, a phenomenon known as up-cycling or supra-recycling [17]. The virtues of reduce are indisputable: new clothes are made from used or unwanted clothes, which reduces the wasting of the resources that were used to make the original textile material by simply discarding them [18]. Further, the reduce of used or unwanted clothes also creates new sources of employment [19]. Reducing is an occupation that demands both effort and the development of skills among the labour force employed, as well as the input of varied raw materials [20], which are mainly derived from what would otherwise be regarded as waste. Manufacturers in many countries have exploited the potential of reducing to create outstanding brands and have produced large quantities of exclusive and handmade clothes [21]. Currently, the challenge is for them to use as much waste as possible in their products. The imagination and talent devoted to producing new garments through reduce represents a more sustainable archetype for commerce in the world of fashion.

In addition, there is now the possibility of developing recycling techniques involving the recovery of the fibres in fabrics through chemical or mechanical processes [22]. Chemical procedures can only be carried out with synthetic fibres while natural fibres of all kinds can be recovered using mechanical procedures. Formerly, such recycled materials were transformed into blankets and woollen coats but nowadays they can also be transformed into mattresses or insulating materials. Mechanical recycling enables considerable savings in the use of new material and consumes less energy [23] and if the materials are divided into different colours and treated in colour batches which also reduces water consumption. Synthetic materials can also be recycled using mechanical techniques [24] and the most common example of such a technique is the recycling of plastic bottles using the PET (Polyethylene Terephthalate) system, In the same way, fibres from waste synthetic textiles can be recovered and recycled. This includes the recycling of polyester by chemical alteration of the polyester polymer into the monomers constituting the polyester. These are then polymerised again in order to obtain a better-quality material than can be achieved by mechanical procedures alone. The recycling of polyester, either by mechanical or chemical means is becoming very important. Currently in Europe, most polyester fibres are obtained from recycled sources derived using the latest technologies [25]. This results in a great saving of energy equivalent annually to the consumption of around 100,000 people [25]. Additionally, there are considerable environmental benefits as well as social benefits to thousands of people and the supply of PET to textile industries can be achieved through alliances with distributors who specialise in recycling [23]. 
The recycling of fibres results in a great saving of resources and should become a routine part of the relationship between textile designers, producers and recyclers [25]. However, there is currently a lack of communication and recyclers have not signalled the need for changes in production processes prior to the manufacture of garments, to both producers and designers, who therefore fail to produce products that favour recycling. Therefore, there has been little global consideration given by the members of the fashion sector, in which the priority has been to ensure that fashion fits perfectly with the demands created by the consumer society [26].

\subsection{The consumer society: Its actions and consequences}

The level of consumption in more developed countries has become excessive and environmentally harmful [27], not only because more vital natural resources, which cannot be easily renewed, are consumed, but also because societies are not well prepared to be able to reverse the critical impacts on the environment, which will have irreversible consequences on the planet. Therefore, there is an urgent need to transform consumption habits and the production processes by which society's requirements and those of their populations are met [28]. Whilst there are many campaigns and other strategies aimed at raising awareness of environmental issues among consumers, these often do not affect consumer behaviour nor how well-informed consumers are. Moreover, it is the socially elite stratum which is to a large extent the destination of business returns. Thus, being fashionable represents a form of aspirational behaviour for the masses and in its most inventive interpretation is one of the most powerful and spontaneous statements of personal desire and the wish to belong to a place or social class [29]. However, fashion contributes to social and environmental degradation through momentary tendencies and invasive advertising, that use and take advantage of the congenital needs of incorporation and difference to hasten sales periods and encourage a constant increase in production [28].
Presently, the way in which clothing design is practiced, thrives in these conditions of social inequality but does not encourage corporate social responsible (CSR) since it is fully incorporated into the market and calculates its success in terms of increased sales and profits [30]. The illusion that more is constantly needed is based on the assumption that the public continually wants more, and companies impose their business ethic to feed the public's aspiration to consume more in order to sustain their commercial agenda of maximising returns. In fashion, the main generators of this economic increase are women since women's clothing represents the largest percentage of the global fashion industry [31,32].

\subsection{Pollution by the textile industry}

The textile industry, in which large volumes of chemicals and reagents are used, is one of the largest collaborators in the pollution of the environment due to the amount of waste it produces, leading to air and water pollution near to production plants [32]. Tables 1 and 2 detail some of the main sources of atmospheric and effluent emissions caused by the textile industry.

The textile manufacturing industry includes various processes such as sizing, dyeing, and other finished product processes $[34,35]$. The most important problem results from chemicals being directly discharged into water bodies, thus triggering water pollution, which affects both human beings and animals, particularly aquatic animals $[35,36]$.

\subsection{Atmospheric emissions}

The atmospheric emissions produced by the textile industry generally arise from the finishing process from the drying and condensation machines [37]. While heating textiles, these generate oil mists, which include oils, plasticisers, and materials which degrade on exposure to heat. Further, waste produced

Table 1. Air emissions released from different textile processes [33]

\begin{tabular}{|c|c|c|}
\hline Process & Sources & Pollutants \\
\hline Energy production & Emissions from boiler & Particulates, $\mathrm{NO}_{x}, \mathrm{SO}_{2}$ \\
\hline $\begin{array}{l}\text { Coating, drying, } \\
\text { curing }\end{array}$ & Emissions from high temperature ovens & Volatile organic components \\
\hline $\begin{array}{l}\text { Cotton handling } \\
\text { activities }\end{array}$ & $\begin{array}{l}\text { Emissions from preparation, carding, combing, } \\
\text { fabric manufacturing }\end{array}$ & Particulates \\
\hline Sizing & Emissions from using sizing compound & Carbon monoxide, sulphur oxide \\
\hline Bleaching & Emissions from using chlorine compound & Chlorine, chlorine dioxide \\
\hline Dyeing & $\begin{array}{l}\text { Disperse dyeing using carriers, sulphur dyeing } \\
\text { aniline dyeing }\end{array}$ & $\mathrm{H}_{2} \mathrm{~S}$, Aniline vapours \\
\hline Printing & Emissions & Hydrocarbons, ammonia \\
\hline Finishing & Resin finishing, heat setting of synthetic fabrics & Formaldehyde, carriers, polymers-lubricating oils \\
\hline Chemical storage & $\begin{array}{l}\text { Emissions from storage tanks for commodity and } \\
\text { chemicals }\end{array}$ & VOCs \\
\hline $\begin{array}{l}\text { Wastewater } \\
\text { treatment }\end{array}$ & Emissions from treatment tanks and vessels & VOCs, toxic emissions \\
\hline
\end{tabular}


Table 2. Effluent discharge from textile industry and effects on health $[35,36]$

\begin{tabular}{|c|c|c|c|}
\hline Process & $\begin{array}{c}\text { Chemical } \\
\text { Discharge }\end{array}$ & Pollutants & Health Effects \\
\hline Sizing & Benzene & Resins, fats, waxes, starch and glucose & Mutagenic and affects central nervous system \\
\hline Dyeing & Sulphate & Sulphides, acetic acid, mordant & Eye and respiratory problem \\
\hline Printing & Nitrate, phosphate & Starch, gums, mordant acids & Harmful health hazards \\
\hline Finishing & Lead & Starch, salts, finishing agents & Suppression of haematological system \\
\hline
\end{tabular}

during the preparation of fibres and their oxidation products produce emissions during weaving [38]. Furthermore, in the heat setting process of resins at high temperatures, vapours of organic compounds are generated and there are also acidic mists that occur during the carbonisation of wool and in some types of spray dye. The solvent vapours generated contain a high number of toxic compounds in different concentrations, which vary depending on the chemical products used during dyeing and finishing. Some of these chemical compounds are preserved in the fibres and then evaporate in the dryers. The emission of ammonia compounds occurs during the stamping process, since these compounds are contained in the pastes which are used in stamping.

Moreover, various powders are produced in the spinning of natural and synthetic fibres and on a smaller scale, almost all textile processes cause dust [39] . Dust alone is not a contaminant, but its appearance can hinder the removal of other compounds [39]. Most textile plants are equipped with filters which are used to trap barely-visible light dust and heavy fumes. In addition, factories use electrostatic precipitators, which are suitable for the entrapment of fine dust, light smoke and micro-atmospheric impurities, and air sterilisers are used to eliminate bacteria.

\subsection{Global warming potential and incineration systems}

The energy recovered by incinerating textile waste, can be used to replace other sources of heat and can also be used as a source of energy to generate electricity. Incineration is the current means of waste treatment used for energy recovery in many countries [40] and the amount of heat and electricity produced which replaces heat and electricity generated from other energy sources, affects the total environmental impact of the production system. Figure 3 shows the global warming potential per tonne of treated textile waste based on the whole production system. In Figures 2 and 3, the total performance of the incineration system in terms of global warming potential and primary energy usage are illustrated. The thermal energy used for the heating supply is based on heat generated from natural gas [40]. As can be seen the most significant contributor to the global warming potential is the incineration step. The total value of the global warming potential is equal to $230 \mathrm{~kg} \mathrm{CO}_{2}$ per tonne of textile waste. The increasing population and the rising standards of living will continue to expand this problem in the future [41].

Figure 3 presents the results for primary energy demand in each step of the incineration system. As can be seen, a large amount of energy is recovered by incinerating the collected textile waste. The amount of energy required for the incineration system is insignificant compared to the amount of energy recovered by the system.

\subsection{The CSR challenges in eco-fashion design and the fashion industry}

In general, the fashion industry is facing great challenges in the area of CSR. As a labour-intensive industry, it needs to show care for its employees' health and the safety of the conditions they work in, not only within individual companies, but also along their supply chain [42]. Cooperation with suppliers and retailers is increasingly important and the supply chain management processes therefore play a major role in the apparel industry [43]. Further, as a resource-intensive sector, it needs to compensate for using the planets' natural resources and mitigate the damage it causes to the natural environment. The textile and clothing industry use a lot of resources during production, and it is therefore important to handle waste efficiently and diminish environmental impact. All those aspects

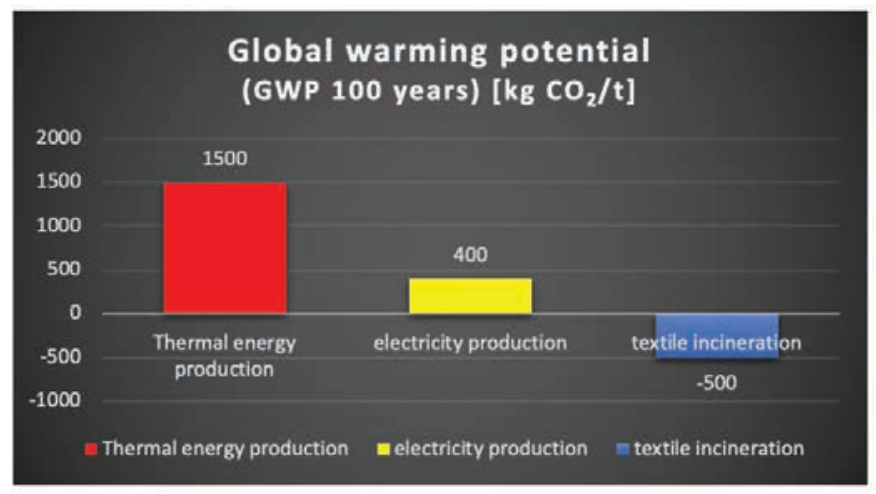

Figure 2. Global warming potential in $\mathrm{kg} \mathrm{CO}_{2}$-equivalent per tonne of textile waste from incineration systems.

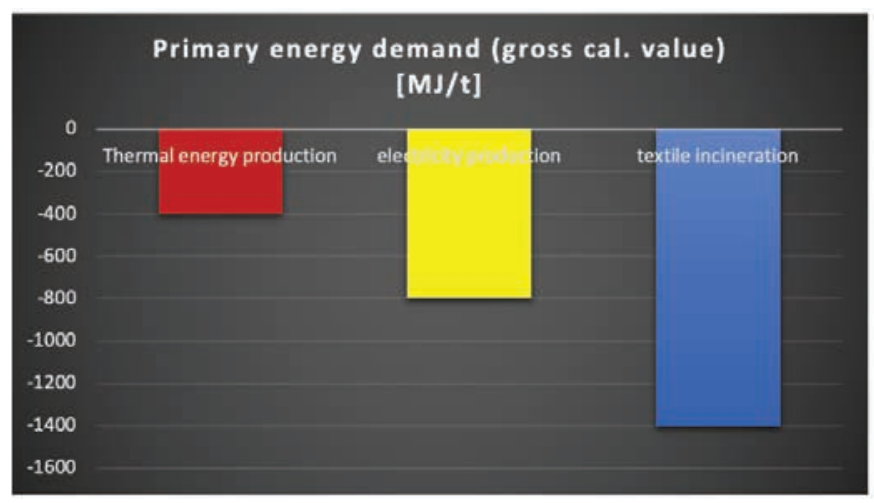

Figure 3. Primary energy demand in gross calorific value for the incineration system. 
make the sector very interesting from a CSR perspective and show that there is the potential for further development towards a socially responsible corporate supply chain. Fashion typically combines the finest materials and top designers seek to create products which every consumer desires [44]. Nevertheless, when people consider the environmental effects that fashion creates, the social responsibility of the fashion industry becomes a major issue. Even high-end consumers have changed from pursuing name-brands and designer fashions to brands that can bring a sustainable approach to the design and manufacture of modern clothing. What is interesting is that fashion brands are not devalued by being socially sustainable and producing clothing and fashion accessories from recycled materials. Consumers may even identify these environmentally responsible brands with their own sense of social responsibility. With higher levels of consumer social and environmental consciousness, fashion brands must inevitably show that they care about the planet as much as their consumers do in order to address the issues involved.

The impact of the consumer society and its relationship with the environment and particularly the responsible use of nonrenewable resources represent a challenge for the textile industry. Most garments that are currently produced for consumption are not designed with the intention of reducing the environmental impact of their production $[45,46]$ and their disposal thus threatens to upset the balance of nature and society as well.

Regrettably, even though there are so many examples of ethical fashion, it is still not easy for the public to buy clothes or bags made from recycled materials that are traded fairly. Consumer consciousness has been changed. Formerly, people simply required a product without any faults but nowadays, that is not enough. People now want a perfect product that has had no adverse side effects. Global apprehensions regarding climate change are inspiring many people to reduce their ecological footprints. People want an ideal product that has no side effects, no defects and is eco-friendly while ensuring proper CSR practice. Consumer beliefs about ethical fashion influence the fashion industry socially and environmentally [47] and integrating environmental and social sustainability related practices into the fashion industry business is more important than in other industries [48]. The CSR movement will benefit the fashion industry and contribute towards the healthy growth of local economies and the development of communities as well contributing to the creation of a sustainable global textile supply chain [49]. The link between CSR and competitiveness is stronger in terms of benefits to the environment and communities achieved throughout the supply chain involving both suppliers and consumers [50]. Transparency in the supply chain and the integration of sustainability act as drivers of change in the textile industry from both a social and environmental perspective [51].

At this point in time, the application of social life cycle assessment would be very beneficial for companies with the best social performance, in terms of their employing sustainable means of production and distribution [52]. CSR behaviour and sustainable practices lead to decision making in the fashion industry which are beneficial to the broader issue of creating sustainable economic systems [53]. However, aspects of supply chain relationship management may be more critical in progressing the implementation of CSR [44]. While CSR represents a rising focus of corporate governance, there are many barriers to its implementation [54]. However, there has been much research attention devoted to the practice of CSR in the textile industry, which has noted the benefits of CSR, not only for the industry, but also for the community and environment. Nevertheless, there is currently only a limited focus within the fashion industry on eco-fashion designing and CSR practices throughout the supply chain. However, it is ecofashion designers who are best placed to take valuable steps towards creating a more sustainable supply chain through the application of ecologically beneficial processes, options and innovations in the production of textile goods.

This study will consider the different eco-friendly opportunities that currently exist, ranging from manufacturing processes to the final product and the role of the designer in the fashion industry. An overview of the different waste and contaminants that may arise in the manufacturing processes will be presented. Finally, the study will reflect on the activity of ecoconscious designers and their commitment to developing a sustainable fashion supply chain. The new challenge for the creators of fashion is not only to innovate morphologically but also to incorporate sustainability in their designs. This could play an important and fundamental role in tackling the issue of environmental pollution caused by the fashion industry and form the focus of a socially responsible corporate supply chain [55-57].

\section{Methodology}

This study used a preferred reporting items for systematic reviews and meta-analyses (abbreviated as 'PRISMA') which is based on a sequential process for choosing the literature items reviewed in order to increase scientific reliability [58]. The study focussed on the academic debate on the expansion of eco-fashion designing and ecological awareness in the textile sector with the intention of offering an external viewpoint. A systematic literature review methodology was employed in which an inclusive search for related studies on an explicit topic is conducted the studies then being synthesized according to a predetermined explicit method [59]. The search and assessment method was conducted according to the process outlined by Tranfield et al. [60]. In the first stage, the main question directing the review was defined by the authors through conversations with other colleagues. The review question addressed was: How can eco-fashion designing ensure corporate social responsibility (CSR) within the supply chain process? Based on the earlier studies reviewed, the goals of the literature review were to accumulate empirical evidence and study cases that would contribute to answering the following questions:

1. What improvements can take place in the processes used by the textile industry? 
2. What is the possibility of reducing waste in the cutting and sewing process?

3. Does fair treatment and labour equity exist in clothesmaking workshops?

4. How can the use of chemical products be reduced in the bleaching and dyeing processes?

5. How can a designer work to propel eco-fashion and benefit from the environmental and economic sustainability of his/ her activity?

The related sources of literature were initially selected based on:

- The identification of relevant book sections and other publications that were not covered by this database.

- The identification of key articles and book sections providing background information on specific topics from other sources, including colleagues.

- A review of the references used in previous related literature reviews.

Additionally, to support this study, we collected some primary data through assessment of factors associated with fashion industry behaviours (KAP- knowledge, attitude and practice) to know CSR and MSWM practice. We investigated four textile and waste separation companies consequently SGMP, Hi-Care Thai Gloves, Hatyai Sirikantawat, and Tenco Rubber which is located in Hatyai municipality, Thailand.

\section{Results}

An automated search was run in a number of academic databases, including Scopus, ISI Web of Science, Emerald, Science Direct, and the Directory of Open Access Journals (DOAJ), in January 2019. The approach used was to classify and scientifically evaluate research papers published from 2012 to 2018, initially based on a careful analysis of the articles' abstracts and conclusion sections. At that point, only publications which were consistent with the study's aims were included for further investigation. Scopus and Web of Science cover a large number of journals in the social sciences and a total of 105 publications in English consisting of books and trade magazines, journal articles and conference proceedings were traced, which included theoretical and conceptual papers, case studies, modelling papers and literature reviews. Figure 4 shows a breakdown of the papers based on their research methodologies.

The distribution over time of the publications traced shows an ambiguous trend. It was anticipated that the sample would cover only a limited number of papers, but it was ascertained that the largest number of papers were published in 2014. It was also found that the literature traced largely neglected the social dimension of the fashion industry. Moreover, between

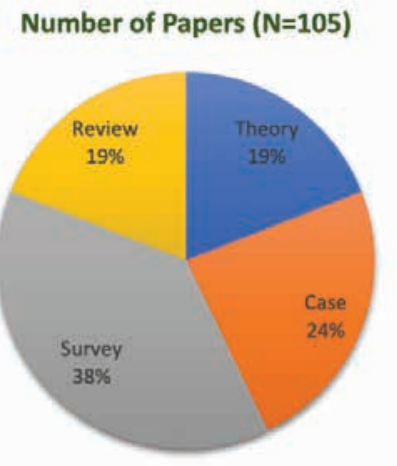

Figure 4. Research methodologies employed in the studies included in the review.

2012 and 2015, the textile/apparel industry faced many issues (e.g. the Rana Plaza accident in Bangladesh) which could be seen as a trigger for researchers to deal with social issues. Regarding the journals in which papers were traced, that with the most articles was the Journal of Business Ethics with ten papers. Five papers were found in the International Journal of Production Economics, with four in the Journal of Cleaner Production. The rest of the papers were dispersed among other journals with a maximum appearance of two papers per journal. Figure 5 below shows the time distribution of the papers analysed.

The search strings used combinations of the keywords: CSR, fashion designing, ecological clothing; responsible supply chain; sustainable clothing. The keywords chosen were used to construct search strings with Boolean connectors, which were used to connect and denote relationships among the various keywords. Boolean searching is a powerful way to specify a search and most search engines include this option, although it can look different depending on the database. Based on logic, Boolean operators include the words AND, OR, and NOT. It is stressed that this research was an exploratory study for which the methodology of a literature review is ideally suited. The coding of the data was conducted by two of the authors. In any case where their views contrasted, the issue was discussed until agreement was reached with the involvement of the other authors if necessary in order to arrive at a reliable mutual conclusion [61].

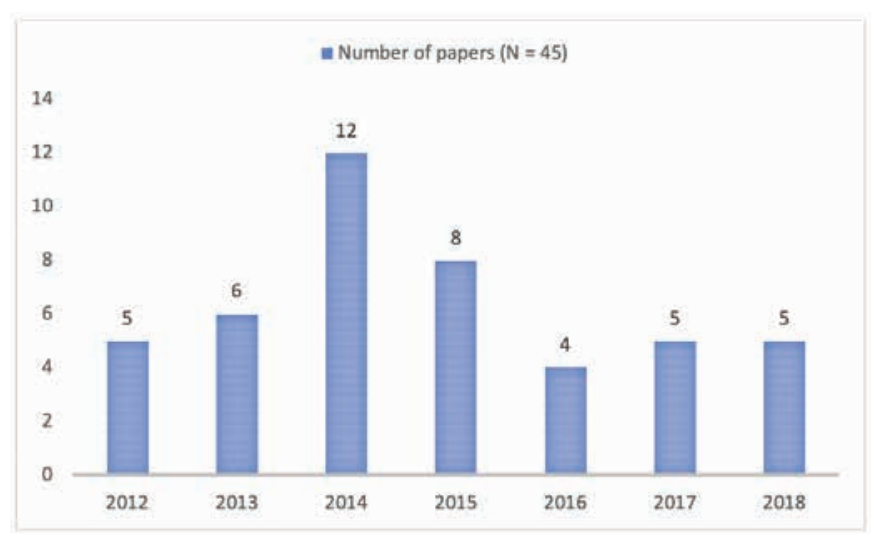

Figure 5. Time distribution of analysed papers. 
The data in terms of the content of the papers traced was coded and then classified within five carefully chosen dimensions: environmental, ethical, economic, legal and social, based on the aims of this paper (Table 3).

Principles for the inclusion and exclusion of publications were applied to refine the list of studies. To improve the scientific value, only peer-reviewed academic articles were included. Moreover, a conventional qualitative content investigation [62] with Atlas Ti was used to scrutinize the texts with coding groups derived inductively from the text (See Figure 6). Atlas Ti is a qualitative data analysis tool, mostly used for large segments of visual, textual or audio data. This software package scrutinises texts and interprets them using coding and annotation [63]. The key investigator/author conducted the selection of the studies and the procedure was checked by all the co-authors.

\subsection{Industry Investigation on Practicing Eco-fashion for MSW management and ensure CSR}

To support this study partially, we investigated solid waste generation from textile manufacturing industry and its composition including the level of knowledge, attitude and practice on MSW in Hatyai municipality which is a part of Southern Thailand in order to propose the guidelines for effective eco-fashion industry. Based on the data obtained through a questionnaire survey conducted by this study, a total of 73 waste disposal sites exist in Southern Thailand wherein amount of waste per day is 477 and 1214 tons by landfill and open dumping accordingly (Table 4). Leachate and Landfill gas are the substantial ecological and environmental emissions from MSW disposal. Landfill gas comprises methane where its global warming potential is 21 times greater than carbon dioxide (Table 5). Methane from MSW open dumpsites and landfill is produced by the action of microorganisms throughout the breakdown of organic matter. Though methane generation from landfill is higher than open dumpsites.

Table 3. Dimensions, coding, and searches related to Textile supply chain sustainability, CSR and related (sample) references

\begin{tabular}{|c|c|c|}
\hline Dimension & Coding of the definition & Example of the search string \\
\hline Environmental & Natural circumstances & $\begin{array}{c}\text { "respect and care for the environment" } \\
\text { "environmental risks" } \\
\text { "contaminated waste" } \\
\text { "industry and pollution creation" } \\
\text { "global warming potentiality" } \\
\text { "environmental regulation" }\end{array}$ \\
\hline Ethical & $\begin{array}{c}\text { Moral principles and rules relating to processes } \\
\text { and practices in the industry }\end{array}$ & $\begin{array}{l}\text { "ensure having the right tech" } \\
\text { "transnational corporations violate human rights" } \\
\text { "corporate corruption" }\end{array}$ \\
\hline Economic & $\begin{array}{l}\text { Economic aspects that impact the processes of } \\
\qquad \text { CSR }\end{array}$ & $\begin{array}{l}\text { "economic development" } \\
\text { "economic globalization" } \\
\text { "fashion market" }\end{array}$ \\
\hline Legal & $\begin{array}{l}\text { Legal influences on the procedures and } \\
\text { practices of the industry }\end{array}$ & $\begin{array}{c}\text { "protection of economic rights "protection of human } \\
\text { rights" } \\
\text { "protection of environmental right" } \\
\text { "labour rights and employment deregulation" }\end{array}$ \\
\hline Social & The effect of industrial growth on society & $\begin{array}{l}\text { "consumer society morality" } \\
\text { "actions and consequences of consumer society" } \\
\text { "consumer perceive value" }\end{array}$ \\
\hline
\end{tabular}

Table 4. Solid waste disposal sites in Southern Thailand

\begin{tabular}{|c|c|c|c|c|c|c|}
\hline \multirow{2}{*}{ Region } & \multicolumn{2}{|c|}{ Number of sites } & \multicolumn{2}{c|}{ Disposal area (rai) } & \multicolumn{2}{c|}{ Amount of waste (tons/day) } \\
\cline { 2 - 7 } & LF & OD & LF & OD & LF & OD \\
\hline Southern Thailand & 17 & 56 & 792 & 1644 & 477 & 1214 \\
\hline
\end{tabular}

Table 5. Methane emission estimation

\begin{tabular}{|c|c|c|c|}
\hline Region & Landfill $(\mathbf{G g} /$ year) & Open dumping (Gg/ year) & Total (Gg/ year) \\
\hline Southern Thailand & 10.86 & 1.90 & 12.76 \\
\hline
\end{tabular}


Records identified through data base searching

$$
(\mathbf{n}=105)
$$

\section{Titles and abstracts screened $(\mathrm{n}=95$ ) \\ Review Type Identification \\ of empirical literature: $n=45$ \\ of normative literature: $n=30$ \\ of mixed literature: $\quad n=\mathbf{2 0}$}

Full texts articles assessed for eligibility ( $n=50)$

of empirical literature: $\quad n=28$

of normative literature: $n=14$

of mixed literature: $\quad n=8$

Sample analysed in Atlas $\mathrm{Ti}$

$(n=45)$

Figure 6. PRISMA flow diagram.

We investigated four textile and waste separation companies explicitly SGMP, Hi-Care Thai Gloves, Hatyai Sirikantawat, and Tenco Rubber to know the factors level associated with fashion industry behaviours (KAP- knowledge, attitude and practice) (Figure 7). Level of knowledge, attitude and practice (KAP) on MSWM was evaluated using open questionnaires. On the level of knowledge and attitude to MSW from fashion industry perspective, respondents score was $80 \%$ and $76 \%$ respectively. However, the level of practice on waste management was amazingly low at $37 \%$. The results led to a recommendation to strengthen waste separation at source, implement waste reduction and recycling concepts and follow up eco-fashion concepts more preferably.

After investigating those companies, we had found out that they try to optimize their textile waste and create a serious amount of fabric loss every month. Moreover, to lower this impact they extremely follow the $3 R$ method. Around $5-8 \%$ of the fabric is loss on the manufacturing process which do keep as so-called waste in a special storage in order to add fashion details on the clothes produce. Instead of throwing them away, they keep these in order to offer to the clients a luxury material solution for their detailed functions. They have all the facility allowing its team to optimize the recycle process. Every created waste is sorted in house and brought to the closest recycling facility. They collect raw materials from waste separation companies to recycle by their own. This system is very common in Europe and in the US but still very rare in Asia specially in Thailand. Most

\section{Duplicates removed $(\mathbf{n}=\mathbf{1 0})$}
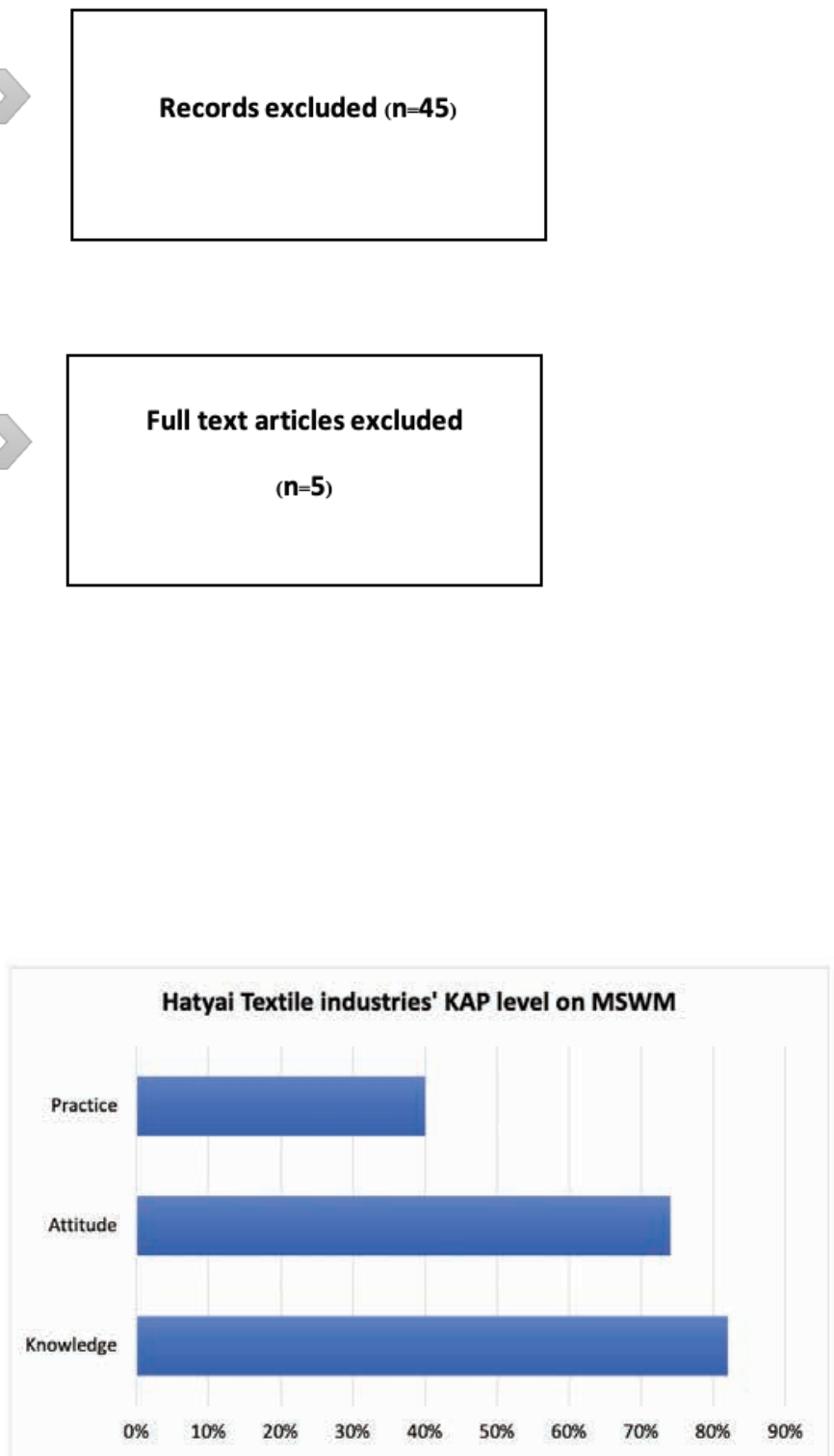

Figure 7. Percentage of KAP level on MSW management.

of them make Yarn from Food crop waste such as pineapple, banana etc. which is totally eco-friendly. They have partnership with a few spinning mills who are capable in ring spinning and using our recycled fibre as raw material. Among 150 survey respondents for MSW management practice, $60 \%$ were female and $40 \%$ were male accordingly. In terms of position, $40 \%$ of respondents were from managerial level, $50 \%$ from employee and $10 \%$ from dealers and suppliers. Apart from awareness, the relations among beliefs, attitudes, behavioural intentions can also play an important role. 


\section{Discussion}

The following subsections provide answers to the research questions set out in section 2:

\subsection{Improvements in the processes in the textile industry}

The development of sustainability requires innovations in the world of fashion [64]. Change is needed to reduce pollution more effectively and to pay more attention to the effect on the environment than is the case today. This change should be carried out in several steps and should ideally involve modifying how waste in workshops during cutting and sewing can be reduced, thus utilising materials in the most effective way. Moreover, the fashion industry has often be identified as having a problem in regard to working conditions and fundamental criteria such as wage levels and working conditions need to be improved.

\subsection{Reduction of waste in the cutting and sewing process}

Certain designers have developed different techniques to create products according to their abilities. In the textile industry, the procedures involved in designing and developing clothing are generally the most efficient and benefit most from the ideas of those involved. In large or medium-sized fashion companies, the designers generally make a sketch with the appropriate specifications. However, issues relating to efficiency in the cutting of the material are the responsibility of the technical team. The problem is that these technicians are not likely to propose solutions relating to the reduction of waste in the manufacture of the designs, since this would be tantamount to questioning the authority of the designer. CAD programs are widely used in the fashion industry and it is usual for the CAD program to determine the effectiveness of the design [65]. But designers can innovate radically [55] and real changes in relation to sustainability could be wrought by them. While new technologies can provide the tools, what will cause a tangible improvement will be the understanding and assertive stance of the designers [66].

\subsection{Fair treatment and labour equity in clothes-making workshops}

During the last two hundred years, the mechanisation of the textile industry and its distribution chain has given power to several countries such as the United States, the United Kingdom, Japan, and within China, Hong Kong [67]. This improvement combined with the globalisation of trade has led to significant progress in these countries. The textile industry is very labour intensive and that is why it has been a fundamental trigger in the development of the working classes in those countries. However, it also leaves them exposed to being exploited by the commercial system. This is very common in the textile cutting and clothing sector. People who come from rural areas to work in the garment industry are unlikely to have knowledge of the labour laws and their rights as employees $[68,69]$. With the widespread exporting of textile industry jobs from developed to developing nations, the consumption and increase in demand in developing countries which have greater purchasing power provide opportunities for employment to workers in developing countries. However, the labour market is not strong enough to ensure the well-being of those workers. There are a number of factors that lead to the fashion industry having multiple opportunities to exploit workers. Two characteristics that stand out in the textile industry are fluctuating demand and the mobility of employment. In the last four decades, the incomes of the inhabitants of the developed countries have increased and garment producing companies have therefore moved their factories to countries where salaries are considerably lower [8]. As a result, a large part of the commitment to the welfare of the workers has been left to the owners of the textile workshops thereby leaving them outside of the sphere of influence of the brands for which they produce garments. Further, because inspection of these factories is very difficult to implement, there is ample opportunity for the abuse of workers and their human rights, since what cannot be seen cannot be controlled.

Nevertheless, campaigns promoted by consumers together with NGOs have been useful in demanding that textile companies develop and implement codes of conduct, to be used in the fashion industry [70]. However, these actions are temporary palliatives to the injustices that occur in workplaces [70]. The Fair-Trade movement also designates those products that favour the use of natural and sustainable materials combined with contemporary designs. In this way, it tries to maintain old and traditional techniques and offers people and their communities fixed and dignified work and the possibility of development without renouncing their identity [71]. Fashion designers are to a large extent responsible for the conditions of the workers who produce their goods because they present very complex creations to production managers often with very demanding time constraints, which put pressure on factory schedules, so that the products arrive in the shops by the required delivery dates. This pressure falls on the workers who are required to work more quickly with a very low salary and this frustrates the commitment of NGOs to improve the conditions of the workers [72]. Given the complexity of the distribution chain, companies can only inspect factories and supplier's factories very infrequently during the year. But if several brands are being supplied by the same workshops, they cannot reliably have a presence in each of them nor can additionally controls by NGOs be provided whenever necessary. Consequently, research shows that in developing countries, the minimum wage by law is far below what is needed to live [5].

Designers can make themselves aware of the results of the decisions they make relation to the speed and value of the distribution chain, thus guaranteeing rapid acceptance and producing creative ideas that add value to the garment without increasing costs excessively [73]. This can diminish the economic oppression suffered by the factory workers and increase the benefit to the factory owners.

\subsection{Reduction in the use of chemical products in the bleaching and dying processes}

The colour of a fabric can inspire and attract the designer or consumer to a certain garment [74] and colour is a very significant element in the design of a fashion garment, which 
must appear attractive in order to achieve its fundamental purpose of transforming the appearance of the wearer, fascinating the consumer, and thus maximizing the likelihood of a purchase [75]. Therefore, it is very important to look for options for colouring fabrics which are friendly to the environment and to reduce the risk of contamination inherent in conventional dyes [76]. One of the main trends in the ecofashion of the early 1990s was unbleached and unstained fabrics, influenced by campaigns opposing the use of chlorine. Chlorine is one of the chemical constituents of both hypochlorite and sodium chlorite, which can cause halogenated organic compounds in wastewater and have been shown to be related to deviation in physiological growth. The methods used in the bleaching of textiles are critical to achieving sustainability since the necessity of repeating the process entails additional resources and is highly polluting [77]. In general, over the last twenty years chlorine has not been used in textile processing [78] and many textile companies dedicated to European and United States markets currently use hydrogen peroxide which entails a high energy cost [79]. Further, additional chemicals are necessary to fix the hydrogen peroxide and optimise the bleaching process. Among them are fixing agents which cause a high degree of contamination if not washed out with water. Moreover, these alternative bleaching techniques entail a higher price, and the economics of the industry relies on not having to eliminate the waste that remains in the water. Another method of bleaching is by using enzymes, and the benefits and disadvantages of bleaching agents and bleaching methods that can be used, have produced more interest in the enzyme technique. Enzymes are used in minimal doses and operate in very specific circumstances and are, therefore, quite simple to control. During bleaching, peroxidase enzymes are applied to neutralise the operation of bleaching by peroxide and thus reduce the potential for contamination. In the dying process, there are many different parameters which control the fastness of the colour that is chosen (among them: the kind of fibre, the dyes, the auxiliary chemicals, the system of use, the class and the age of the machines, and the density of the water). However, in the end, what defines a dying technique as sustainable or not is nature. In the usual dyeing processes, reactive dyes are the most common used for cellulose fibres, such as cotton, which has a lower fixation speed [80]. The residue of the dye remains in the water after dyeing and other chemical agents used to facilitate the fixation process, in addition to chemical dyes, will also increase the danger of contamination [81]. When cellulosic fibres are stained with reactive dyes, considerable amounts of salt are used to generate superior exhaustion $[82,83]$ while in the case of coloured polyester fibres with synthetic disperse dyes, the chemical agents used with the dye include diffusers and dyeing agents. The use of low decision-ratio techniques reduces both the portion of water drawn from natural sources and the portion of toxic water that is discharged back into natural waterways after dying [84]. The objective of using natural dyes is not to respond to the self-imposed dispositions of the industry, but to produce colours within the parameters of nature and adjust them to the imagination and the exercise of the profession [85]. In recent decades, natural dyes have been rarely used by the textile industry [86]. Natural dyes produce colours which occur naturally and are also attractive to the eye and are relaxing and also environmentally friendly while helping to reduce pollution, and thus minimising effects on human health. Accordingly, many companies around the world have developed garments using natural dyes [87]. The main benefit of the development of ecological fashion is that there is less environmental pollution from the industry catering for it. One advantage of eco-fashion garments is that they are produced with materials manufactured from plants grown without pesticides $[88,89]$. Sustainable designs are not only made with products derived from crops grown without toxic chemicals, but also employ materials derived from the $3 \mathrm{Rs}$, which helps to reduce the use of new materials in their production [90]. In addition, eco-fashion is more durable, and the products are of a higher quality so that users need to buy fewer clothes less frequently [91].

\subsection{The designer as a propeller of eco-fashion}

Eco-fashion is important for the environment because it brings a variety of benefits that help to protect the planet and contribute to a socially responsible corporate supply chain [89]. Designers are among the primary initiators and promoters of eco-fashion, which is beneficial for the world and for the health of its inhabitants [44]. The activity of the eco-developer designer can instigate economic sustainability that will harmonise textile business with sustainability decisions.

\section{a. The activity of the eco-developer designer}

In fashion production, there are several changes being driven from the inside outwards. Designers and those who work in the textile industry are gradually coming to appreciate that the work they are doing is to a large extent to satisfy the needs of the fashion consumer chain. Some designers are, moreover, committed to protecting the environment [92]. It is important therefore to deliver knowledge to consumers about the real impact of the purchase of clothing that is not friendly to the environment [93]. It is also much simpler to make the culturally informed consumer believe that his purchase is responsible if he has some understanding of the ecology. In this way the concept of sustainability is used as a marketing action seeking to differentiate the brand from its competitors including those which are not so ecologically active. In a certain way the consumer is de-culturized, is an ecological neophyte. This delays the process of awareness and restructuring of the textile industry to improve its relationship with the planet [94,95]. The solution will not simply come from one company, but the world needs to implement plans and actions at all levels. To encourage the fashion sector to adopt more sustainable practices, there must be a more intense and extensive discussion regarding the effects of the current practises and a communication shift that educates its inhabitants about ecology [95]. This presents an opportunity for environmentally aware designers to disseminate their new perspective of fashion and sustainability. Fashion will not be defined by a handful of prestigious brands. Fashion designers will have the chance to showcase their talents to a global audience and individuals will have the choice and the means to support their favourite brands, in whatever niche that may be [13]. 
The term eco-developer designer covers several concepts [96]. They include the initiator and communicator designers. The initiating designer can refer to the initial activity of beginning to apply the concept of ecological clothing and beginning to modify conventional methods and modes of production [97]. Meanwhile, the communicator, which embodies the main characteristic of this type of designer, makes the concept of ecological clothing known to consumers through the media. Since communication is a fundamental element in raising awareness in society making known the alternatives that exist in relation to conventional fashion will in itself be a contribution towards caring for and preserving the ecology of the planet [98].

\section{b. Eco-fashion design, designers and economic sustainability}

Any attempt to incorporate sustainability into a company's operations will fail if the company cannot economically sustain itself [99]. For eco-fashion designers, instigating economic sustainability will mean harmonising their business with sustainability decisions [100]. Such designers must highlight three paradigms in making a commitment to sustainability:

- Prioritising sustainability above profit margin.

- Concentrating on sustainability inventiveness.

- Understanding the importance of product price for consumers.

Working sustainably entails a reconsideration of what establishes commercial success. It also often means conducting business in direct antagonism to common industry standards since sustainability initiatives are generally motivated by personal moral standards [101]. Further, designers who work to be economically sustainable will prioritise sustainability efforts rather than focussing on other business aims, which may be impossible in such a multifaceted industry [57]. To achieve the goal of sustainability, designers will need to emphasise the specific areas they care most about or feel may have the most fruitful impact.

The final major consideration for designers committed to sustainability relates to product pricing. One of the biggest obstacles for sustainability is that consumers assume that they will be able to obtain more goods for less money [102]. At present, consumers' outlook on the price of garments is highly influenced by the low prices that presently prevail in the fashion industry. Therefore, when consumers' expectations are much lower than the cost of producing sustainably, designers experience pricing issues. While consumer price expectations can lead to design inadequacy, sustainable designers have no choice but to be cognizant of consumers' expectations during the design procedure.

\section{Conclusions}

This study scrutinised problems related to sustainability in the fashion supply chain and how new methods can be brought to bear to solve them. It also sought to identify suitable measures which the fashion industry should adopt, which may assist it to develop a more the socially responsible approach. Realizing the full potential for sustainability in the industry requires that it adopts approaches not only in designing products and procedures but also in global communication. It is also suggested that the environmental problems caused by the fashion industry can be solved through implementing a sustainable approach to the clothing supply chain process.

Nevertheless, many companies profess to be unaware of the damage that their products can generate in the environment. The media is a very useful tool for designers who must take the initiative and promulgate eco-fashion, and through the media, reach consumers and make known the benefits of these eco-fashion garments in relation to the environment. In this study there were some notable achievements which can be summarized in three aspects. Firstly, its findings assist the comprehension of the current situation of waste in the fashiongarment supply chain. It also identifies the methods which could be adopted towards eco-fashion designing, a socially responsible supply chain and the commercial environment in the fashion industry. Secondly, this study scrutinised the practices that are manifested in new methods aimed at reducing the problems related to achieving sustainability in the fashion supply chain. Finally, it was observed that eco-fashion designers must take the first step towards a more sustainable supply chain through insisting on the application of processes, options and innovations relevant to ecologically friendly textiles.

In addition, this study attempted to cover aspects that designers often miss such as the nature of the materials and the methods applied to the production of ecologically friendly garments. These aspects of textile production have begun to modify the methods of the fashion industry by the simple fact of their existence. The role of fashion experts is to accept these practices and others, to take new paths, protect the efforts of others, invest in business, support research and progress, and to provide fertile ground for new ideas to increase. With the passage of time, these actions will modify activity in the fashion supply chain and the representation that its products and services have in society. It is possible to reach the conclusion that it is the ecofashion designer who must take the first step towards a more sustainable supply chain through the application of processes, options and innovations in ecologically friendly textiles. In this way, the use and consumption of these sustainable garments can be promoted through communication, with the aim of achieving a better quality of life for society and benefit for the planet, and this is the strength of the approach advocated in this paper. This study endeavoured to elucidate how the ecofashion designing can promote CSR practice within the supply chain in the textile industry. A key contribution is to provide a better understanding of how eco-fashion designers can be key contributors, who can take the first step towards a more sustainable supply chain through the application of processes, options and innovations in ecological textiles. 
This paper is not without its limitations as the analysis was limited to publications listed by a restricted number of databases. However, the databases searched cover a large proportion of the academic and industry-based studies currently conducted and the study presented herein is thus a useful foundation upon which to base further studies of this nature. A further limitation is entailed in the selection of the period during which the articles etc. appeared in journals or books which covered only the seven years from 2012 to 2018 . This might represent a considerable limitation since earlier research might have focused more on the topics covered by the present study and could thus add usefully to the conclusions reached. Moreover, this study was, as noted above, restricted to the social sciences; scientific disciplines such as the natural and medical sciences were specifically excluded. Further studies should seek to identify the factors that influence eco-fashion design within the supply chain to ensure CSR practices, within a broader research context, and thus act as a guide to the concepts, techniques and processes of eco-fashion designing.

\section{Acknowledgements}

The authors would like to acknowledge a research grant from "Thailand Science Research and Innovation" (TSRI). Grant Number: ENV6405051S.

\section{References}

[1] Whitmore A. The emperors new clothes: sustainable mining? Journal of Cleaner Production. 2006;14(3-4):30914.

[2] Gupta S, Gentry JW. The behavioral responses to perceived scarcity-the case of fast fashion. The International Review of Retail, Distribution and Consumer Research. 2016;26(3):260-71.

[3] Palomo-Lovinski N, Hahn K. Fashion design industry impressions of current sustainable practices. Fashion Practice. 2014;6(1):87-106.

[4] Payne A. Teaching sustainable fashion through ethics and encounters. Journal of the Home Economics Institute of Australia. 2018;25(1):2.

[5] Wood J. Bioinspiration in Fashion-A Review. Biomimetics. 2019;4(1):16.

[6] Köhler M. Reusing Garments: An investigation of influencers to return used garments. 2018.

[7] Wu L, Subramanian N, Abdulrahman MD, Liu C, Lai K-h, PawarKS. The impact of integrated practices of lean, green, and social management systems on firm sustainability performance-evidence from Chinese fashion auto-parts suppliers. Sustainability. 2015;7(4):3838-58.

[8] Bonacich E. Asian and Latino Immigrants in the Los Angeles Garment Industry: An Exploration of the. Info. 1990;5.

[9] Güyer GT, Nadeem K, Dizge N. Recycling of pad-batch washing textile wastewater through advanced oxidation processes and its reusability assessment for Turkish textile industry. Journal of Cleaner Production. 2016;139:488-94.

[10] Lin $H$, Brown LP, Long AC, editors. Modelling and simulating textile structures using TexGen. Advanced Materials Research; 2011: Trans Tech Publ.
[11] Othman N, Mili N, Zailani SN, Mohammad NAB. Extraction of remazol brilliant orange $3 R$ from textile wastewater using tetrabutyl ammonium bromide. Jurnal Teknologi. 2010;53(1):29-39.

[12] Park J-W. 3R policies of Korea. Ministry of Environment, Seoul. 2009.

[13] Anguelov N. The dirty side of the garment industry: Fast fashion and its negative impact on environment and society: CRC Press; 2015.

[14] Norris L. Trade and transformations of secondhand clothing: Introduction. Textile. 2012;10(2):128-43.

[15] Dissanayake G, Sinha P. An examination of the product development process for fashion remanufacturing. Resources, Conservation and Recycling. 2015;104:94102.

[16] Hollanders $H$, Van Cruysen A. Design, creativity and innovation: A scoreboard approach. Pro Inno Europe, Inno Metrics: Holanda, Hui, D, Ng, C, Mok, P, Ngai, F, Wan-kan, $C$, \& Yuen, C(2005) A study on creativity index Hong Kong: Home Affairs Bureau. 2009.

[17] Gwilt A, Rissanen T. Shaping sustainable fashion: Changing the way we make and use clothes: Routledge; 2012.

[18] Bhatia D, Sharma A, Malhotra U. Recycled fibers: an overview. International Journal of Fiber and Textile Research. 2014;4(4):77-82.

[19] King AM, Burgess SC, ljomah W, McMahon CA. Reducing waste: repair, recondition, remanufacture or recycle? Sustainable development. 2006;14(4):257-67.

[20] Chari N, Diallo C, Venkatadri U. Optimal unlimited freereplacement warranty strategy using reconditioned products. International Journal of Performability Engineering. 2013;9(2):191-200.

[21] AVRAM TM. TRENDS IN CLOTHING INDUSTRY BY USE OF THE FORECAST-ROMANIA vs. EXTERNAL ENVIRONMENT. European Journal of Business and Social Sciences. 2017;6(08):01-9.

[22] Moon KK-L, Youn C, Chang JM, Yeung AW-h. Product design scenarios for energy saving: A case study of fashion apparel. International Journal of Production Economics. 2013;146(2):392-401.

[23] Davis G, Song J. Biodegradable packaging based on raw materials from crops and their impact on waste management. Industrial crops and products. 2006;23(2):147-61.

[24] Wang Y. Fiber and textile waste utilization. Waste Biomass Valoriz 1: 135-143. 2010.

[25] Intini F, Kühtz S. Recycling in buildings: an LCA case study of a thermal insulation panel made of polyester fiber, recycled from post-consumerPET bottles. The international journal of life cycle assessment. 2011;16(4):306-15.

[26] Earley R, Vuletich C, Goldsworthy K, Politowicz K, Ribul $M$. The textile toolbox: New design thinking, materials and processes for sustainable fashion textiles: Full research report. 2016.

[27] Sachs W. Ecology, justice, and the end of development. Environmental Justice: Routledge; 2017. p. 19-36.

[28] Roos S, Sandin G, Zamani B, Peters G, Svanström M. Will clothing be sustainable? Clarifying sustainable fashion. Textiles and clothing sustainability: Springer; 2017. p. 1-45. 
[29] Tak P, Pareek A, Rishi B. Social Comparison of Luxury Fashion Brands: Impact of Ostentation and Media Habits. IUP Journal of Marketing Management. 2017;16(1).

[30] Maloney C. The economic impact of the fashion industry. US House of Representatives. 2015.

[31] Al-Halah Z, Stiefelhagen R, Grauman K, editors. Fashion forward: Forecasting visual style in fashion. Proceedings of the IEEE International Conference on Computer Vision; 2017.

[32] Dris R, Gasperi J, Mirande C, Mandin C, Guerrouache M, Langlois $V$, et al. A first overview of textile fibers, including microplastics, in indoor and outdoor environments. Environmental Pollution. 2017;221:453-8.

[33] Karthik T, Gopalakrishnan D. Impact of textiles on environmental issues. Part-II, Asian Dyer. 2013:45-51.

[34] Saini RD. Textile organic dyes: polluting effects and elimination methods from textile waste water. Int $\mathrm{J}$ Chem Eng Res. 2017;9:121-36.

[35] Ozturk E, Koseoglu H, Karaboyacı M, Yigit NO, Yetis U, Kitis M. Minimization of water and chemical use in a cotton/ polyester fabric dyeing textile mill. Journal of cleaner production. 2016;130:92-102.

[36] Letcher TM, Vallero DA. Waste: A handbook for management: Academic Press; 2019.

[37] Heydebreck F, Tang J, Xie Z, Ebinghaus R. Emissions of per-and polyfluoroalkyl substances in a textile manufacturing plant in China and their relevance for workers' exposure. Environmental science \& technology. 2016;50(19):10386-96.

[38] Hasanbeigi A, Price L. A technical review of emerging technologies for energy and water efficiency and pollution reduction in the textile industry. Journal of Cleaner Production. 2015;95:30-44.

[39] Marmo L, Sanchirico R, Di Benedetto A, Di Sarli V, Riccio $D$, Danzi E. Study of the explosible properties of textile dusts. Journal of Loss Prevention in the Process Industries. 2018;54:110-22.

[40] Nunes L, Matias J, Catalão J. Analysis of the use of biomass as an energy alternative for the Portuguese textile dyeing industry. Energy. 2015;84:503-8.

[41] Koszewska M. Circular economy-Challenges for the textile and clothing industry. Autex Research Journal. 2018;18(4):337-47.

[42] Dickson MA, Eckman M. Social responsibility: The concept as defined by apparel and textile scholars. Clothing and Textiles Research Journal. 2006;24(3):178-91.

[43] de Abreu MCS. Perspectives, drivers, and a roadmap for corporate social responsibility in the textile and clothing industry. Roadmap to sustainable textiles and clothing: Springer; 2015. p. 1-21.

[44] Perry P, Towers N. Conceptual framework development: CSR implementation in fashion supply chains. International Journal of Physical Distribution \& Logistics Management. 2013;43(5-6):478-501.

[45] Fletcher K. Exploring demand reduction through design, durability and 'usership'of fashion clothes. Philosophical Transactions of the Royal Society A: Mathematical, Physical and Engineering Sciences. 2017;375(2095):20160366.

[46] Laitala KM, Boks C, Klepp IG. Making clothing last: A design approach for reducing the environmental impacts. 2015.
[47] Choi TM, Lo CK, Wong CW, Yee RW, Shen B, Wang Y, et al. The impact of ethical fashion on consumer purchase behavior. Journal of Fashion Marketing and Management: An International Journal. 2012.

[48] Thorisdottir TS, Johannsdottir L. Sustainability within fashion business models: A systematic literature review. Sustainability. 2019;11(8):2233.

[49] Chi T. Building a sustainable supply chain: an analysis of corporate social responsibility (CSR) practices in the Chinese textile and apparel industry. Journal of the Textile institute. 2011;102(10):837-48.

[50] Choi T-M, Li Y. Sustainability in fashion business operations. Multidisciplinary Digital Publishing Institute; 2015.

[51] Khurana K, Ricchetti M. Two decades of sustainable supply chain management in the fashion business, an appraisal. Journal of Fashion Marketing and Management. 2016.

[52] Lenzo P, Traverso M, Salomone R, loppolo G. Social life cycle assessment in the textile sector: an Italian case study. Sustainability. 2017;9(11):2092.

[53] Li Y, Zhao X, Shi D, Li X. Governance of sustainable supply chains in the fast fashion industry. European Management Journal. 2014;32(5):823-36.

[54] Zhu D, Tan KH. Issues and challenges of CSR practices in textile industry: an empirical study in Suzhou, China. International Journal of Management and Enterprise Development. 2008;5(6):759-72.

[55] Kozlowski A, Searcy C, Bardecki M. The reDesign canvas: Fashion design as a tool for sustainability. Journal of Cleaner Production. 2018;183:194-207.

[56] Kozlowski A, Bardecki M, Searcy C. Tools for sustainable fashion design: An analysis of their fitness for purpose. Sustainability. 2019;11(13):3581.

[57] Lawless E, Medvedev K. Assessment of sustainable design practices in the fashion industry: experiences of eight small sustainable design companies in the Northeastern and Southeastern United States. International Journal of Fashion Design, Technology and Education. 2016;9(1):4150.

[58] Moher D, Liberati A, Tetzlaff J, Altman DG, Altman D, Antes $G$, et al. Preferred reporting items for systematic reviews and meta-analyses: The PRISMA statement (Chinese edition). Journal of Chinese Integrative Medicine. 2009;7(9):889-96.

[59] Denyer D, Tranfield D. Producing a systematic review. 2009.

[60] Tranfield D, Denyer D, Smart P. Towards a methodology for developing evidence-informed management knowledge by means of systematic review. British journal of management. 2003;14(3):207-22.

[61] Jarvis CB, MacKenzie SB, Podsakoff PM. A critical review of construct indicators and measurement model misspecification in marketing and consumer research. Journal of consumer research. 2003;30(2):199-218.

[62] Hsieh H-F, Shannon SE. Three approaches to qualitative content analysis. Qualitative health research. 2005;15(9):1277-88.

[63] Konopásek Z. Making thinking visible with Atlas. ti: Computer assisted qualitative analysis as textual practices. Historical Social Research/Historische Sozialforschung Supplement. 2007:276-98. 
[64] Remy N, Speelman E, Swartz S. Style that's sustainable: A new fast-fashion formula. McKinsey \& Company. 2016:1-6.

[65] Tao J, Li L, Yu S. An innovative eco-design approach based on integration of $L C A, C A D \backslash C A E$ and optimization tools, and its implementation perspectives. Journal of Cleaner Production. 2018;187:839-51.

[66] Singh S, Acharya A. Big data, knowledge co-creation and decision making in fashion industry. 2018.

[67] Hitz E. A technical and business revolution: American woolens to 1832: Routledge; 2017.

[68] Zhu H, Wang P, Bart C. Board processes, board strategic involvement, and organizational performance in for-profit and non-profit organizations. Journal of Business Ethics. 2016;136(2):311-28.

[69] Solís M. GENDER TRANSITIONS ALONG BORDERS.

[70] Boström M, Micheletti M. Introducing the sustainability challenge of textiles and clothing. Journal of Consumer Policy. 2016;39(4):367-75.

[71] Sorger R, Udale J. The fundamentals of fashion design: Bloomsbury Publishing; 2017.

[72] Pfeiffer J. International NGOs and primary health care in Mozambique: the need for a new model of collaboration. Social science \& medicine. 2003;56(4):725-38.

[73] Bruce M. Lucy daly and Neil Towers. Lean or Agile: A Solution for Supply Chain Management in the Textile and Clothing Industry.24(2):151-70.

[74] Vivek SD, Beatty SE, Morgan RM. Customer engagement: Exploring customer relationships beyond purchase. Journal of marketing theory and practice. 2012;20(2):12246.

[75] McClendon E. 30-Second Fashion: The 50 Key Modes, Garments, and Designers, Each Explained in Half a Minute: Ivy Press; 2016.

[76] Verma A, DASH RB. P.(2012) A review on chemical coagulation-flocculation technologies for removal of colour from textile wastewater. Environmental Management.93:154-68.

[77] Imtiazuddin S, Mumtaz M, Mallick KA. Pollutants of wastewater characteristics in textile industries. J Basic Appl Sci. 2012;8:554-6.

[78] Kant R. Textile dyeing industry an environmental hazard. 2011.

[79] Ciriminna R, Albanese L, Meneguzzo F, Pagliaro M. Hydrogen Peroxide: A Key Chemical for Tomorrow's Sustainable Development. ChemSusChem. 2016.

[80] Broadbent $A D$, Therien N, Zhao Y. Effects of process variables on the fixation of reactive dyes to cotton using infrared radiation. Industrial \& engineering chemistry research. 1995;34(3):943-7.

[81] Manley JB, Anastas PT, Cue Jr BW. Frontiers in Green Chemistry: meeting the grand challenges for sustainability in $R \& D$ and manufacturing. Journal of Cleaner Production. 2008;16(6):743-50.

[82] Ray D, Sarkar BK, Bose NR. Impact fatigue behaviour of vinylester resin matrix composites reinforced with alkali treated jute fibres. Composites Part A: applied Science and manufacturing. 2002;33(2):233-41.

[83] Shah DU, Schubel PJ, Clifford MJ, Licence P. Fatigue life evaluation of aligned plant fibre composites through $S-N$ curves and constant-life diagrams. Composites Science and Technology. 2013;74:139-49.
[84] Kocabas AM, Yukseler H, Dilek FB, Yetis U. Adoption of European Union's IPPC Directive to a textile mill: Analysis of water and energy consumption. Journal of environmental management. 2009;91(1):102-13.

[85] Angelis-Dimakis A, Alexandratou A, Balzarini A. Value chain upgrading in a textile dyeing industry. Journal of Cleaner Production. 2016;138:237-47.

[86] Pisitsak P, Tungsombatvisit N, Singhanu K. Utilization of waste protein from Antarctic krill oil production and natural dye to impart durable UV-properties to cotton textiles. Journal of Cleaner Production. 2018;174:1215-23.

[87] Ali A, Hossain D, Shahid M. Development of Ecofriendly Garments Washing for Localized Fading Effect on Garments: A Future Sustainable Process for Single Step Dyeing Fading Effect. Adv Res Text Eng. 2018;3(1):1022.

[88]Begum Z, Kumar KK. Global Environmental Requirements-Textile Industry. A Study of India's Textile Exports and Environmental Regulations: Springer; 2018. p. 61-72.

[89] Lundblad L, Davies IA. The values and motivations behind sustainable fashion consumption. Journal of Consumer Behaviour. 2016;15(2):149-62.

[90] Despeisse $M$, Ford $S$, editors. The role of additive manufacturing in improving resource efficiency and sustainability. IFIP International Conference on Advances in Production Management Systems; 2015: Springer.

[91] Wagner M, Chen Y, Curteza A, Thomassey S, Perwuelz $A$, Zeng $X$, editors. Fashion design solutions for environmentally conscious consumers. IOP Conference Series: Materials Science and Engineering; 2017.

[92] Calamari S, Hyllegard KH. An exploration of designers perspectives on human health and environmental impacts of interior textiles. Textiles and Clothing Sustainability. 2017;2(1):9.

[93] Cooper R, Press M. The Design Experience. Gower Press, London; 2003.

[94] Franco MA. Circular economy at the micro level: A dynamic view of incumbents' struggles and challenges in the textile industry. Journal of Cleaner Production. 2017;168:833-45.

[95] Niemann W, Kotzé T, Mannya K. Global sourcing risk management approaches: A study of small clothing and textile retailers in Gauteng. The Southern African Journal of Entrepreneurship and Small Business Management. 2018;10(1):1-15.

[96] Joy A, Sherry Jr JF, Venkatesh A, Wang J, Chan R. Fast fashion, sustainability, and the ethical appeal of luxury brands. Fashion theory. 2012;16(3):273-95.

[97] Yagoubi A, Tremblay D-G. Being a fashion designer in Montreal: flexible careers across the life course! Journal of Human Resources and Sustainability Studies. 2016;4(3):215-26.

[98] Ioan CC, CarceaMI.AWARENESSANDENVIRONMENTAL ATTITUDE IN THE CONTEXT SUSTAINABLE DEVELOPMENT WITHIN A KNOWLEDGE-BASED SOCIETY. Environmental Engineering \& Management Journal (EEMJ). 2013;12(8).

[99] Scherhorn G. Sustainability, consumer sovereignty, and the concept of the market. Consumers, Policy and the Environment A Tribute to Folke Ölander: Springer; 2005. p. 301-10. 
[100] Bos-Brouwers HEJ. Corporate sustainability and innovation in SMEs: evidence of themes and activities in practice. Business strategy and the environment. 2010;19(7):417-35.

[101] Dahl AL. Achievements and gaps in indicators for sustainability. Ecological indicators. 2012;17:14-9.

[102] McGouran C, Prothero A. Enacted voluntary simplicity-Exploring the consequences of requesting consumers to intentionally consume less. European Journal of Marketing. 2016. 